\title{
UKURAN PERUSAHAAN, PROFITABILITAS, DAN LEVERAGE TERHADAP ISLAMIC SOCIAL REPORTING PADA BANK UMUM SYARIAH DI INDONESIA
}

\author{
Umiyati dan Muhammad Danis Baiquni \\ Fakultas Ekonomi dan Bisnis, UIN Syarif Hidayatullah Jakarta \\ Email: umiyati@uinjkt.ac.id
}

\begin{abstract}
This research discusses the effect of firm size, profitability, and leverage on Islamic Social Reporting (ISR) at Sharia Commercial Bank in Indonesia. The sample is 8 Syariah Commercial Banks in Indonesia within the period from 2011 to 2015. Dependent variable in this research is ISR, using method of content analysis. Firm size is measured by total company asset, profitability is matched by ROA and ROE, as well as leverage is measured by DAR is an independent variable. The method of analysis is multiple linear regression using panel data and processed using Eviews version 9.0. The result shows simultaneously firm size, ROA, ROE, and DAR effect against ISR. That partially only variable of firm size that significant effects to ISR, while ROA, ROE and DAR has no significant effect to ISR.
\end{abstract}

Keywrods: Islamic Social Reporting, Company Size, Profitability, Leverage

\section{PENDAHULUAN}

Isu lingkungan di Indonesia sedang hangat dibicarakan masyarakat pada akhir dekade ini, khususnya dampak yang disebabkan oleh kegiatan dari perusahaan (Kamil dan Herustya, 2012). Kepedulian perusahaan akan lingkungan dan masyarakat baik diluar dan didalam perusahaan dikenal dengan sebutan Corporate Social Responsibility (CSR). CSR merupakan sebuah gagasan yang menjadikan perusahaan tidak lagi dihadapkan pada tanggung jawab single bottom line, yaitu hanya pada kondisi keuangan. Namun, dengan berkembangnya konsep triple bottom line yang dikemukakan oleh John Elkington pada tahun 1997, perusahaan kini dihadapkan pada tiga konsep yaitu profit, people, dan planet (Apriyanti dan Budiasih, 2016). Praktik pengungkapan CSR telah banyak diterapkan oleh perusahaan publik di Indonesia. Walaupun secara umum praktek CSR lebih banyak dilakukan oleh perusahaan tambang maupun manufaktur, namun, saat ini industri perbankan termasuk perbankan syariah telah melakukan pengungkapan CSR walaupun dalam bentuk yang relatif sederhana.

Islam mengajarkan bahwa tidak cukup bagi seorang Muslim hanya menfokuskan diri beribadah kepada Allah SWT. Dalam Islam, manusia merupakan khalifah dimuka bumi, sehingga manusia juga harus menyemarakkan kebaikan kepada sesama makhluk ciptaan-Nya. Oleh sebab itu, kesempurnaan iman seorang muslim tidak hanya dapat dicapai dengan 
hubungan vertikal kepada Allah saja (Hablumminallah), tetapi juga harus dibarengi dengan hubungan yang baik kepada sesama makhluk ciptaan Allah (Hablumminannas) (Sofyani dkk., 2012).

Praktik pengungkapan CSR telah banyak diterapkan oleh perusahaan publik di Indonesia. Walaupun secara umum praktek CSR lebih banyak dilakukan oleh perusahaan tambang maupun manufaktur, namun, seiring dengan adanya tren global akan praktik CSR, saat ini industri perbankan juga telah mengungkapkan aspek pertanggunggjawaban sosial dalam laporan tahunannya walaupun dalam bentuk yang relatif sederhana. Pengungkapan tersebut tidak hanya dilakukan oleh perbankan konvensional tetapi juga dilakukan oleh perbankan syariah.

Secara umum fungsi bank syariah yaitu, pertama manajer Investasi, kedua investor, ketiga penyedia jasa keuangan dan lalu lintas pembayaran, dan keempat pengemban fungsi sosial. Tiga fungsi pertama merupakan fungsi bisnis, sedangkan fungsi ke empat adalah fungsi sosial bank syariah. Disamping itu, konsep perbankan Islam juga mengharuskan bank-bank syariah untuk memainkan peran penting di dalam pengembangan sumber daya manusianya dan memberikan kontribusi bagi perlindungan dan pengembangan lingkungan (Wiroso, 2009).

Fungsi sosial bank syariah makin dipertegas dalam UU No.21 Tahun 2008 Tentang Perbankan Syariah. Pada pasal 4 dinyatakan, bahwa selain berkewajiban menjalankan fungsi intermediasi keuangan, bank syariah dan UUS dapat menjalankan fungsi sosial dalam bentuk lembaga baitul mal, yaitu menghimpun dana yang berasal dari zakat, infak, sedekah, hibah, atau dana sosial lainnya serta menyalurkannya kepada organisasi pengelola zakat. selain itu, bank syariah juga dapat menghimpun dana sosial yang berasal dari wakaf uang dan menyalurkannya kepada pengelola wakaf (nazhir) sesuai dengan kehendak pemberi wakaf (wakif).

Walaupun bersifat sukarela, namun fungsi sosial pada bank syariah merupakan prinsip syariah yang mengharuskan bank syariah untuk beroperasi dengan landasan moral, etika, dan tanggung jawab sosial. Selain itu adanya prinsip atas ketaatan pada perintah Allah dan yang terakhir adanya prinsip atas kepentingan umum, terdiri dari penghindaran dari kerusakan lingkungan dan kemiskinan (Fitria dan Hartanti, 2010). Pelaporan CSR sendiri merupakan praktik pelaksanaan kegiatan yang dilakukan berdasarkan nilainilai norma yang berlaku di masyarakat. Pada sektor perbankan syariah, nilainilai norma yang digunakan adalah nilai-nilai agama Islam, atau disebut juga dengan nilai-nilai syariah (Azhar dan Trisnawati, 2013).

Sejauh ini pengukuran pengungkapan CSR pada perbankan syariah masih mengacu kepada Global Reporting Initiative Index (Indeks GRI). Padahal, prinsip atau pedoman GRI masih menggunakan prinsip yang bersifat konvensional, maka kurang tepat jika digunakan untuk menjadi tolak ukur dalam pengungkapan CSR pada perbankan syariah. Berdasarkan prinsip-prinsip Islam, transaksi-transaksi bisnis tidak pernah dipisahkan dari tujuan-tujuan moral dalam masyarakat. Pemerintah-pemerintah di negaranegara berpopulasi Muslim seperti Malaysia dan Indonesia serta institusi- 
institusi regulator internasional seperti Accounting and Auditing Organization for Islamic Financial Institutions (AAOIFI) secara terus menerus menyuarakan dan mengupayakan adanya pengembangan dan adopsi format pelaporan semacam laporan CSR untuk diformulasikan bagi lembagalembaga keuangan Syariah (Muhammad, 2009).

Terkait dengan adanya kebutuhan mengenai pengungkapan kinerja sosial di perbankan syariah, saat ini marak diperbincangkan mengenai Islamic Social Reporting Index (Sofyani dkk., 2012). Islamic Social Repoorting (ISR) pertama kali dikemukakan oleh Haniffa (2002) dalam penelitiannya yang berjudul Social Reporting Disclosure: An Islamic Perspective, adanya keterbatasan dalam pengungkapan laporan sosial konvensional yang hanya berfokus kepada aspek material dan moral. Oleh karena itu, perlu adanya kerangka khusus untuk pelaporan pertanggungjawaban sosial yang sesuai dengan prinsip syariah, dengan menjadikan aspek spiritual sebagai fokus utama dalam pelaporan tanggung jawab sosial perusahaan, karena para pembuat keputusan muslim memiliki ekspektasi agar perusahaan mengungkapkan informasi secara sukarela guna membantu dalam pemenuhan kebutuhan spiritual mereka. Sehingga akhirnya disusun suatu kerangka konseptual ISR berdasarkan ketentuan syariah yang dapat membantu perusahaan dalam melakukan pemenuhan kewajiban terhadap Allah SWT, masyarakat serta lingkungan. Setiap perusahaan skala besar ataupun kecil yang ada dalam pelaksanaan operasionalnya pasti menimbulkan dampak bagi lingkungan sekitar perusahaan tersebut. Oleh karena itu diharapkan perusahaan dapat mengungkapkan CSR lebih luas lagi (Haniffa, 2002). Kemudian penelitian tersebut dikembangkan oleh Othman dan Thani (2010) dalam penelitiannya yang berjudul Islamic Social Reporting Of Listed Companies In Malaysia, ISR sendiri terdiri dari enam tema pengungkapan, yaitu keuangan dan investasi, produk/jasa, karyawan, masyarakat, lingkungan, dan tata kelola perusahaan. Indeks ISR merupakan tolak ukur pelaksanakaan kinerja sosial perbankan syariah yang berisi kompilasi indikator standar CSR yang ditetapkan oleh AAOIFI (Accounting and Auditing Organization for Islamic Financial Institutions).

Pertumbuhan bank syariah di Indonesia juga mendorong lahirnya etika pengungkapan tanggung jawab sosial. Sebagai entitas yang berbasis syariah, sudah sepatutnya bank syariah memperhatikan lingkungan dan masyarakat sekitar sebagai bentuk kepedulian dan tanggung jawab terhadap umat (Rosiana dkk., 2015). Tetapi, pada praktiknya bank syariah di Indonesia dalam melakukan pelaporan tanggung jawab sosial perusahaan belum mengacu pada indeks ISR yang merupakan suatu metode dalam pelaporan kegiatan tanggung jawab sosial perusahaan dengan prinsip-prinsip Islam. Padahal perkembangan indeks ISR cukup pesat di negara-negara Islam lainya, seperti Malaysia, Sudan, Bahrain, Uni Emirat Arab, Iran, Palestina, Kuwait, Bangladesh, dan Qatar yang telah menjadikan indeks ISR sebagai bagian dari pelaporan organisasi syariah di negara-negara yang bersangkutan (Fitria dan Hartanti, 2010). 
Beberapa bukti empiris mendukung adanya pengaruh tehadap pengungkapan ISR yang menemukan bahwa ukuran perusahaan mempunyai pengaruh signifikan terhadap pengungkapan ISR. Hal ini karena dengan perusahaan yang lebih besar sudah pasti memiliki pembiayaan, fasilitas, dan sumber daya manusia yang lebih banyak dibandingkan dengan perusahaan yang lebih kecil, demikian juga pada tingkat profitabilitas memiliki pengaruh signifikan terhadap pengungkapan ISR (Widyawati dan Raharja, 2012). Hal ini menggambarkan suatu kondisi ketika perusahaan memiliki laba yang tinggi berarti perusahaan menganggap perlu mengungkapkan informasi yang lebih luas dalam melaksanakan kegiatan CSR perusahaan. Kemudian dalam penelitian lain mengungkapkan bahwa leverage berpengaruh terhadap pengungkapan Islamic Social Reporting dengan slope negatif. Hal ini menggambarkan bahwa tingkat utang pada bank syariah yang tinggi akan mengurangi pengungkapan kegiatan sosial perusahaan, begitu pula sebaliknya.

\section{TELAAH TEORITIS DAN PENGEMBANGAN HIPOTESIS}

\subsection{CORPORATE SOCIAL RESPONSIBILITY (CSR)}

Definisi mengenai CSR atau tanggung jawab sosial perusahaan sekarang ini masih sangat luas dan beragam. Belum adanya definisi secara umum tentang CSR membuat pengertian CSR memiliki perbedaan menurut beberapa organisasi. Corporate Social Responsibility (CSR) memiliki beberapa tujuan dalam pelaksanaan kegiatannya. Dari sisi filosofi konvensional, terdapat beberapa teori yang melatarbelakangi pelaksanaan CSR dalam perusahaan, yaitu (Fitria dan Hartanti, 2010):

a. Teori Kapitalisme.

Teori ini digagas oleh Friedman (1967) yang mengungkapkan apabila perusahaan melakukan aktivitas CSR di luar kepentingan para pemegang sahamnya, maka kegiatan tersebut telah menyalahi tujuan perusahaan. Satu-satunya kewajiban perusahan dan termasuk CSR didalamnya adalah memberikan kemakmuran kepada pemegang saham. Aktivitas donasi dibolehkan jika diproyeksikan dapat memberikan keuntungan bagi perusahaan dan bukan sekedar filantropi.

b. Teori Kontrak Sosial.

Teori kontrak sosial yang digagas oleh Moir (2001) meyakini bahwa perusahaan hanya dapat berusaha dengan baik jika didukung oleh masyarakat sekitarnya. Sehingga dalam hal ini perusahaan akan dianggap sebagai institusi sosial yang harus berkontribusi kepada lingkungan sosialnya.

c. Teori Instrumen. 
Burke dan Logsdon (1996) berpendapat bahwa CSR dipandang sebagai alat strategi untuk mencapai tujuan perusahaan. Sehingga menurut teori ini perusahaan dalam melakukan aktivitas CSR memiliki tujuan tertentu seperti menciptakan reputasi yang positif, kehumasan atau manfaat sejenis lainnya.

d. Teori Legitimasi.

Teori ini dikemukakan oleh Deegan (2002), yaitu bahwa perusahaan akan melakukan aktivitas CSR dikarenakan adanya tekanan sosial, politik dan ekonomi dari luar perusahaan. Sehingga perusahaan akan menyeimbangkan tuntutan tersebut dengan melakukan hal yang diinginkan oleh masyarakat dan yang diharuskan oleh peraturan.

e. Teori Stakeholder.

Clarkson (1995) mengatakan bahwa Aktivitas CSR menurut dilakukan untuk mengakomodasi keinginan dan kebutuhan pemangku kepentingan (stakeholder), sehingga perusahaan dapat beraktivitas dengan baik dengan seluruh dukungan pemangku kepentingan tersebut.

\subsection{ISLAMIC SOCIAL REPORTING (ISR)}

Islamic Social Reporting (ISR) pertama kali digagas oleh Roszaini Haniffa pada tahun 2002 dalam jurnal yang berjudul "Social Reporting Disclosure: An Islamic Perspective" yang merupakan pengembangan dari kerangka syariah (the sharia framework) yang telah digagas terlebih dahulu oleh Haniffa dan Hudaib (2002), kemudian kerangka syariah ini menjadi landasan dasar atas terbentuknya ISR yang komprehensif. Kerangka syariah ini akan menghasilkan aspek-aspek material, moral, dan spiritual dalam indeks ISR perusahaan. ISR lebih lanjut dikembangkan secara lebih ekstensif oleh Othman, Thani dan Ghani E.K (2009) di Malaysia.

Masih terdapat banyak keterbatasan dalam pelaporan sosial konvensional, sehingga dalam penelitian ini mengemukakan kerangka konseptual ISR yang berdasarkan ketentuan syariah. ISR tidak hanya membantu pengambilan keputusan bagi pihak muslim melainkan juga untuk membantu perusahaan dalam melakukan pemenuhan kewajiban terhadap Allah dan masyarakat (Haniffa, 2002).

Secara khusus indeks ISR adalah perluasan dari social reporting yang meliputi harapan masyarakat mengenai peran perusahaan yang tidak hanya dalam perekonomian, tetapi juga peran perusahaan dalam perspektif spiritual. Selain itu, indeks ISR juga menekankan pada keadilan sosial terkait pelaporan mengenai lingkungan, hak minoritas, dan karyawan (Fitria dan Hartanti, 2010). Bentuk akuntabilitas dan transparansi merupakan tujuan dalam pelaksanaan tanggung jawab sosial perusahaan secara syariah. Bukan hanya tanggung jawab kepada para pemangku kepentingan tetapi juga secara khusus terhadap Allah SWT dan kepada masyarakat pada umumnya. Masyarakat juga berhak mengetahui informasi yang relevan mengenai perusahaan dalam menjalankan kegiatan bisnisnya. Oleh karena itu 
akuntabilitas dan transparansi menjadi poin penting dalam indeks ISR. Berikut adalah tujuan dan bentuk akuntabilitas serta transparansi dalam ISR menurut Roszaini Haniffa yang disajikan dalam tabel1 berikut:

Tabel 1. Bentuk Akuntabilitas dan Transparansi Dalam ISR

\section{Tujuan ISR:}

1. Sebagai bentuk akuntabilitas kepada Allah SWT dan masyarakat

2. Meningkatkan transparansi kegiatan bisnis dengan menyajikan informasi yang relevan dengan memperhatikan kebutuhan spiritual investor muslim atau kepatuhan syariah dalam pengambilan keputusan.

Bentuk Akuntabilitas:

1. Menyediakan prduk yang halal dan baik

2. Memenuhi hak-hak Allah dan masyarakat

3. Mengejar keuntungan yang wajar sesuai dengan prinsip Islam

4. Mencapai tujuan usaha bisnis

5. Menjadi karyawan dan masyarakat

6. Memastikan kegiatan usaha yang berkelanjutan secara ekologis

7. Menjadikan pekerjaan sebagai bentuk ibadah

\section{Bentuk Transparansi:}

1. Memberikan informasi mengenai semua kegiatan halal dan haram dilakukan

2. Memberikan informasi yang relevan mengenai pembiayaan dan kebijakan investas

3. Memberikan informasi yang relevan mengenai kebijakan karyawan

4. Memberikan informasi yang relevan mengenai hubungan dengan masyarakat

5. Memberikan informasi yang relevan mengenai penggunaan sumber daya dan perlindungan lingkungan

Sumber: diolah dari (Haniffa, 2002)

Indeks ISR adalah poin-poin pengungkapan yang digunakan sebagai indikator dalam pelaporan kinerja sosial institusi bisnis syariah. Pada awal pembentukannya, indeks ISR hanya berisikan lima tema yang di kembangkan dalam penelitian Haniffa (2002) dalam pengungkapan Indeks ISR, yaitu Tema Pembiayaan dan Investasi, Tema Produk dan Jasa, Tema Karyawan, Tema Masyarakat, dan Tema Lingkungan. Kemudian dikembangkan lagi oleh Othman dan Thani (2010) pada tabel 2 menambahkan dengan satu tema pengungkapan yaitu Tema Tata Kelola Perusahaan.

Tabel 2. Tema Pengungkapan Islamic Social Reporting

\begin{tabular}{ll}
\hline No & \multicolumn{1}{c}{ Tema Pengungkapan ISR } \\
\hline 1 & Tema Pembiayaan dan Investasi \\
\hline 2 & Tema Produk dan Jasa \\
\hline 3 & Tema Karyawan \\
\hline 4 & Tema Masyarakat \\
\hline 5 & Tema Lingkungan \\
\hline 6 & Tema Tata Kelola Perusahaan \\
\hline
\end{tabular}




\subsection{UKURAN PERUSAHAAN (SIZE)}

Ukuran perusahaan dilihat dari total asset yang dimiliki oleh perusahaan, yang dapat dipergunakan untuk kegiatan operasional perusahaan. Jika perusahaan memiliki total asset yang besar, pihak manajemen akan lebih leluasa dalam mempergunakan aset yang ada di perusahaan tersebu (Dewi dan Wirajaya, 2013).

Nilai total asset perusahaan dapat diperoleh dari laporan posisi keuangan pada akhir periode perusahaan dalam laporan tahunan perusahaan. Nilai total asset perusahaan dapat dilihat pada bagian aktiva dalam laporan keuangan perusahaan. Aktiva adalah manfaat ekonomi yang mungkin diperoleh di masa depan, atau dikendalikan oleh entitas tertentu sebagai hasil dari transaksi atau kejadian masa lalu (Widyawati dan Raharja, 2012).

\subsection{PROFITABILITAS}

Rasio profitabilitas menggambarkan kemampuan perusahaan dalam mendapatkan laba melalui semua kemampuan dan sumber daya yang dimiliki, seperti kegiatan penjualan, kas, modal, jumlah karyawan, jumlah cabang, dan sebagainya (Harahap, 2010).

Terdapat beberapa jenis rasio profitabilitas yang dapat digunakan untuk mengukur nilai profitabilitas perusahaan. Masing-masing jenis rasio profitabilitas digunakan untuk menilai serta mengukur posisi keuangan perusahaan dalam suatu periode tertentu atau untuk beberapa periode. Rasio ini juga memberikan ukuran tingkat efektivitas manajemen suatu perusahaan. Penggunaan rasio profitabilitas secara menyeluruh dapat menjelaskan tingkat efektivitas perusahaan dalam menghasilkan laba secara lebih menyeluruh pula. Hal ini ditunjukkan oleh laba yang dihasilkan dari penjualan dan pendapatan investasi (Kasmir, 2010). Jenis rasio profitabilitas yang dipakai dalam penelitian ini adalah ROA dan ROE.

ROA merupakan rasio yang menunjukkan hasil (return) atas jumlah aktiva yang digunakan dalam perusahaan. ROA berfungsi untuk mengukur efektifitas perusahaan dalam menghasilkan laba dengan memanfaatkan aktiva yang dimiliki. Rasio ROA juga sering dipakai untuk menilai kinerja bank secara umum. Semakin besar ROA yang dimiliki suatu perusahaan, maka semakin efisien pula penggunaan aktiva yang dimiliki perusahaan dalam mendapatkan peningkatan laba.

Hasil pengembalian ekuitas atau return on equity merupakan rasio untuk mengukur laba bersih sesudah pajak dengan modal sendiri. Rasio ini menunjukkan efisiensi penggunaan modal sendiri. Semakin tinggi rasio ROE, maka semakin baik pula perusahaan dalam menggunakan ekuitas perusahaan untuk menghasilkan laba.

\subsection{LEVERAGE}

Rasio leverage menggambarkan hubungan antara utang perusahaan terhadap modal maupun asset. Rasio ini dapat melihat seberapa jauh perusahaan dibiayai oleh utang atau pihak luar dengan kemampuan perusahaan yang 
digambarkan oleh modal maupun aset (Harahap, 2010). Pada penelitian ini rasio leverage yang digunakan adalah debt to asset ratio (DAR). Debt to asset ratio merupakan rasio utang yang digunakan untuk mengukur perbandingan antara total utang dengan total aktiva. Apabila rasionya tinggi, artinya pendanaan dengan utang semakin banyak, maka semakin sulit bagi perusahaan untuk memperoleh tambahan pinjaman karena dikhawatirkan perusahaan tidak mampu menutupi utang-utangnya dengan aktiva yang dimilikinya. Demikian pula apabila rasio rendah, semakin kecil perusahaan dibiayai dengan utang dalam menjalankan kegiatan operasionalnya.

\subsection{PERUMUSAH HIPOTESIS PENELITIAN}

$\mathrm{H}_{01}$ : Tidak terdapat pengaruh yang signifikan dari ukuran perusahaan (size) terhadap Islamic Social Reporting (ISR) secara parsial.

$\mathrm{H}_{\mathrm{a} 1}$ : Terdapat pengaruh yang signifikan dari ukuran perusahaan (size) terhadap Islamic Social Reporting (ISR) secara parsial.

$\mathrm{H}_{02}$ : Tidak terdapat pengaruh yang signifikan dari Return on Asset (ROA) terhadap Islamic Social Reporting (ISR) secara parsial.

$\mathrm{H}_{\mathrm{a} 2}$ : Terdapat pengaruh yang signifikan dari Return on Asset (ROA) terhadap Islamic Social Reporting (ISR) secara parsial.

$\mathrm{H}_{03}$ : Tidak terdapat pengaruh yang signifikan dari Return on Equity (ROE) terhadap Islamic Social Reporting (ISR) secara parsial.

$\mathrm{H}_{\mathrm{a} 3}$ : Terdapat pengaruh yang signifikan dari Return on Equity (ROE) terhadap Islamic Social Reporting (ISR) secara parsial.

$\mathrm{H}_{04}$ : Tidak terdapat pengaruh yang signifikan dari leverage terhadap Islamic Social Reporting (ISR) secara parsial.

$\mathrm{H}_{\mathrm{a} 4}$ : Terdapat pengaruh yang signifikan dari leverage terhadap Islamic Social Reporting (ISR) secara parsial.

$\mathrm{H}_{05}$ : Tidak terdapat pengaruh yang signifikan antara ukuran perusahaan (size), profitabilitas, dan leverage terhadap Islamic Social Reporting (ISR) secara simultan.

$\mathrm{H}_{\mathrm{a} 5}$ : Terdapat pengaruh yang signifikan antara ukuran perusahaan (size), profitabilitas, dan leverage terhadap Islamic Social Reporting (ISR) secara simultan

\section{METODE PENELITIAN}

Jenis Penelitian ini merupakan penelitian asosiatif dengan menggunakan data sekunder yang diperoleh dari laporan tahunan perusahaan masing-masing bank umum syariah yang terdapat pada website resmi perusahaan pada periode 2011-2015. Informasi lain sebagai penunjang data penelitian 
diperoleh dari laporan Statistik Perbankan Syariah Bank Indonesia dan Otoritas Jasa Keuangan pada periode 2011-2015, serta berbagai literatur dari buku dan internet.

Penelitian ini menggunakan metode analisis regresi linear berganda dengan data panel yaitu gabungan antara data cross-section dan time series. Data ISR diperoleh menggunakan metode content analysis yaitu dengan memberikan skor 1 untuk setiap item yang diungkapkan dan skor 0 jika tidak diungkapkan pada laporan tahunan perusahaan. Analisis isi dalam penelitian merupakan teknik penelitian yang dapat ditiru dan sahih untuk membuat inferensi-inferensi dari teks pada pernyataan yang kaya akan makna lain dari konteks penggunaannya (Krippendorff, 2004).

Data yang telah terkumpul selanjutnya diolah menggunakan program E-VIEWS V.9. Analisis data penelitian ini terbagi menjadi 2 (dua) yaitu statistik deskriptif dan statistik inferensial. Statistik deskriptif digunakan untuk menggambarkan tingkat pengungkapan ISR. Statistik inferensial dengan cara regresi linear berganda dengan data panel digunakan untuk mengetahui pengaruh antara variabel independen dengan variabel dependen (Sugiyono, 2008).

Populasi dalam penelitian ini adalah 12 Bank Umum Syariah (BUS) di Indonesia yang beroperasi pada tahun 2011-2015. Perusahaan yang menjadi sampel penelitian adalah perusahaan yang dipilih bedasarkan metode purposive sampling dengan kreteria sebagai berikut:

a. BUS yang beroperasi di Indonesia dari tahun 2011-2015.

b. BUS yang mempublikasikan laporan tahunan dari tahun 2011-2015.

Berdasarkan kriteria yang diajukan tersebut, sehingga terdapat 8 (delapan) Bank Umum Syariah yang menjadi sampel penelitian yaitu, Bank Muamalat Indonesia (BMI), Bank BRI Syariah (BRIS), Bank BNI Syariah (BNIS), Bank Syariah Mandiri (BSM), Bank BCA Syariah (BCAS), Bank Syariah Bukopin (BSB), Bank Panin Syariah (BPS), dan Bank Mega Syariah (BMS)

Variabel penelitian yang digunakan dalam penelitian ini adalah sebagai berikut:

\section{Variabel Terikat (Dependen Variabel)}

Variabel terikat yang digunakan dalam penelitian ini adalah pengungkapan Islamic Social Reporting (ISR). Indeks ISR diukur menggunakan metode content analysis. Metode ini mengidentifikasi jenis pengungkapan ISR dengan cara membaca dan menganalisis laporan tahunan perusahaan. Prosedur penggunaan analisis isi dalam penelitian ini yaitu dengan mengamati dan menganalisa informasi dan pesan yang disampaikan melalui dokumen yang berupa laporan tahunan perusahaan. Penilaian dalam analisis isi dapat berupa rasio metriks dengan cara memberikan skor pada setiap indikator yang menjadi objek penelitian. Skor 1 diberikan untuk setiap indikator yang terdapat pada penyampaian informasi dan skor 0 untuk setiap indikator yang tidak terdapat pada penyampaian informasi. Selanjutnya data 
yang telah diperoleh akan diolah dengan membandingkan skor yang terpenuhi dengan jumlah indikator penelitian. Rumusnya adalah sebagai berikuRumus untuk menghitung adalah sebagai berikut (Krippendorff, 2004):

$$
\text { Disclosure Level }=\frac{\text { Jumlah skor disclosure yang terpenuhi }}{\text { Jumlah skor disclosure maksimum }} \times 100
$$

2. Variabel Bebas (Independen Variabel)

a. Ukuran Perusahaan

Ukuran perusahaan dilihat dari total asset yang dimiliki oleh perusahaan, yang dapat dipergunakan untuk kegiatan operasional perusahaan. Jika perusahaan memiliki total asset yang besar, pihak manajemen akan lebih leluasa dalam mempergunakan aset yang ada di perusahaan tersebut. Rumus untuk menghitung adalah sebagai berikut (Dewi dan Wirajaya, 2013):

$$
\text { Size }=\text { Ln (Total Aset) }
$$

\section{b. Profitabilitas}

ROA merupakan rasio yang menunjukkan hasil (return) atas jumlah aktiva yang digunakan dalam perusahaan. ROA berfungsi untuk mengukur efektifitas perusahaan dalam menghasilkan laba dengan memanfaatkan aktiva yang dimiliki. ROA dapat dihitung dengan menggunakan rumus sebagai berikut (Ikatan Bankir Indonesia, 2014):

$$
\mathrm{ROA}=\frac{\text { Laba Bersih }}{\text { Total Aset }} \times 100 \%
$$

Hasil pengembalian ekuitas atau return on equity merupakan rasio untuk mengukur laba bersih sesudah pajak dengan modal sendiri. Rasio ini menunjukkan efisiensi penggunaan modal sendiri. Semakin tinggi rasio ROE, maka semakin baik pula perusahaan dalam menggunakan ekuitas perusahaan untuk menghasilkan laba. ROE dapat dihitung dengan menggunakan rumus sebagai berikut (Ikatan Bankir Indonesia, 2014) :

$$
\mathrm{ROE}=\frac{\text { Laba Bersih }}{\text { Total Ekuitas }} \times 100 \%
$$

\section{c. Leverage}

Rasio leverage menggambarkan hubungan antara utang perusahaan terhadap modal maupun asset. Rasio ini dapat melihat seberapa jauh perusahaan dibiayai oleh utang atau pihak luar dengan kemampuan perusahaan yang digambarkan oleh modal maupun aset (Harahap, 2010). DAR dapat dihitung dengan menggunakan rumus sebagai berikut (Kasmir, 2010):

$$
\mathrm{DAR}=\frac{\text { Total Utang }}{\text { Total Aset }} \times 100 \%
$$




\section{HASIL DAN PEMBAHASAN}

\subsection{ANALISIS DESKRIPTIF}

Data yang sudah dikumpulkan dan dihitung selanjutnya akan diolah dan dianalisis dengan menggunakan statistik deskriptif oleh peneliti. Statistik deskriptif memberikan gambaran atau deskripsi suatu data yang dilihat dari nilai rata-rata (mean), standar deviasi, varian, maksimum, minimum, sum, range, kurtosis dan skewness (kemencengan distribusi) (Ghazali dan Ratmono, 2013). Berikut ini adalah hasil dari pengujan statistik deskriptif:

Tabel 3. Hasil Uji Statistik Deskriptif

\begin{tabular}{lccrrr}
\hline Keterangan & $\begin{array}{c}\text { ISR } \\
\text { (Dalam } \\
\text { Persen) }\end{array}$ & $\begin{array}{c}\text { SIZE } \\
\text { (Dalam Miliaran } \\
\text { Rupiah) }\end{array}$ & $\begin{array}{c}\text { ROA } \\
\text { (Dalam } \\
\text { Persen) }\end{array}$ & $\begin{array}{c}\text { ROE } \\
\text { (Dalam } \\
\text { Persen) }\end{array}$ & $\begin{array}{c}\text { DAR } \\
\text { (Dalam } \\
\text { Persen) }\end{array}$ \\
\hline Mean & 69.08 & 20.210 & 1.14 & 10.96 & 22.71 \\
\hline Minimum & 44.00 & 1.017 & 0.08 & 0.44 & 2.80 \\
\hline Maximum & 91.00 & 70.370 & 3.81 & 64.84 & 93.26 \\
\hline Std. Dev. & 11.58 & 22.109 & 0.82 & 13.71 & 20.84 \\
\hline Observations & 40 & 40 & 40 & 40 & 40 \\
\hline \multicolumn{7}{c}{ Sumber: Data diolah oleh penulis (dalam pembulatan) } \\
\end{tabular}

Berdasarkan hasil tabel 3, nilai observasi menunjukan banyaknya data yang digunakan dalam penelitian, yaitu sebanyak 40 data yang merupakan jumlah sampel selama periode penelitian dari tahun 2011 sampai dengan tahun 2015. Variabel ISR memiliki nilai rata-rata sebesar $69,08 \%$, nilai minimum sebesar $44 \%$, nilai maksimum sebesar $91 \%$, dan standar deviasi sebesar 11,58\%, damn untuk variabel size yang disajikan dalam Miliaran Rupiah memiliki nilai rata-rata sebesar 20.210 Miliar Rupiah, nilai minimum sebesar 1.017 Miliar Rupiah, nilai maksimum sebesar sebesar 70.370 Miliar Rupiah, dan standar deviasi sebesar 22.109 Miliar Rupiah.

Variabel Return on Assets memiliki nilai rata-rata sebesar 1,14\%, nilai minimum $0,08 \%$, nilai maksimum sebesar sebear $3,81 \%$, dan standar deviasi sebesar $0,82 \%$ sedangkan variabel Return on Equity memiliki nilai rata-rata sebesar $10,96 \%$, nilai minimum $0,44 \%$, nilai maksimum sebesar sebesar $64,84 \%$, dan standar deviasi sebesar $13.71 \%$ dan variabel Debt to Asset Ratio memiliki nilai rata-rata sebesar $22,71 \%$, nilai minimum $2,8 \%$, nilai maksimum sebesar sebear 93,26\%, dan standar deviasi sebesar 20,84\%.

Berdasarkan grafik 1, terlihat bahwa tema lingkungan yang paling sedikit diungkapkan bank syariah pada laporan tahunan perusahaan dengan persentase sebesar 24\%. Rendahnya pengungkapan ISR pada tema lingkungan, dapat diambil kesimpulan bahwa bank syariah saat ini masih kurang menyadari pentingnya melestarikan lingkungan.

Berdasarkan hasil content alalysis maka diperoleh hasil ISR sebagai berikut: 
Grafik 1. Pengungkapan ISR bedasarkan Tema

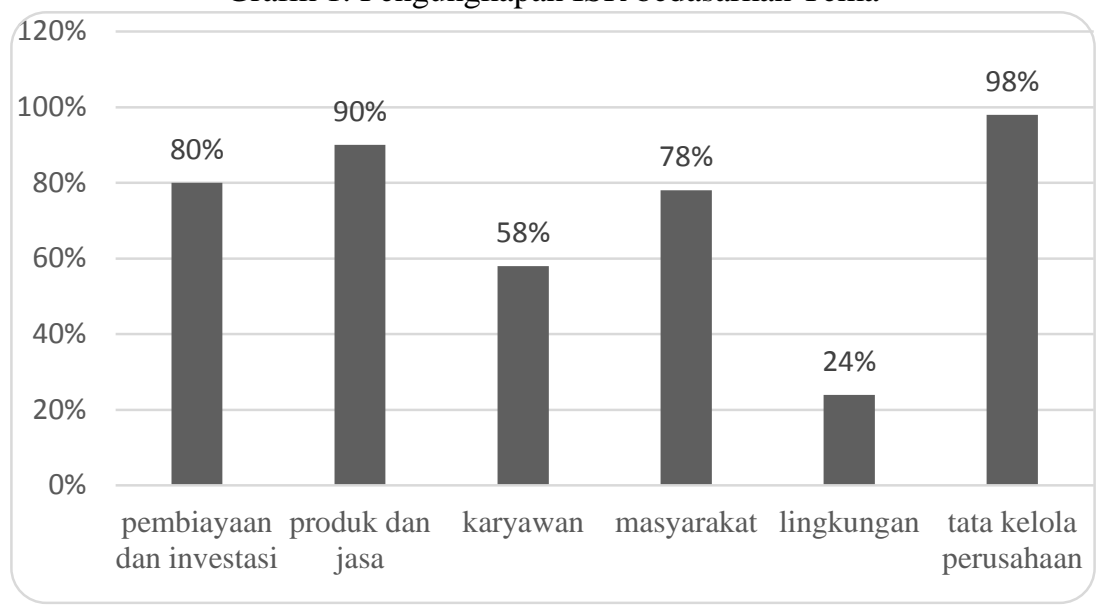

Sumber: Data diolah oleh penulis

\subsection{ANALISI REGRESI LINIER BERGANDA}

Analisis regresi linier berganda dalam penelitian ini menggunakan metode regresi data panel, dalam regresi data panel terdapat 3 model estimasi, yaitu estimasi Pooled Least Square (PLS), Fixed Effect Model (FEM) dan Random Effect Model (REM). Sebelum melakukan estimasi model dalam regresi linier berganda, terlebih dahulu dilakukan Uji Stasioneritas dan Uji Asumsi Klasik.

1. Uji Stasioneritas

Tabel 4. Hasil Uji Stasioneritas

\begin{tabular}{lrcrc}
\hline \multirow{2}{*}{ Variabel } & \multicolumn{4}{c}{ Tingkat Stasioneritas } \\
\cline { 2 - 5 } & \multicolumn{2}{c}{ Level } & \multicolumn{2}{c}{ First Difference } \\
\cline { 2 - 5 } & Probabilitas & Keterangan & Probabilitas & Keterangan \\
\hline ISR & 0.0125 & Stasioner & 0.0000 & Stasioner \\
\hline SIZE & 0.0669 & Tidak Stasioner & 0.0000 & Stasioner \\
\hline ROA & 0.0038 & Stasioner & 0.0000 & Stasioner \\
\hline ROE & 0.0012 & Stasioner & 0.0000 & Stasioner \\
\hline DAR & 0.0473 & Stasioner & 0.0000 & Stasioner \\
\hline
\end{tabular}

Sumber: Data diolah oleh penulis

Berdasarkan hasil uji stasioneritas pada tabel 4 dapat dilihat bahwa pada tingkat awal terdapat data yang tidak stasioner, kemudian setelah melakukan unit root test pada semua variabel di tingkat first different maka semua data telah stasioner pada tingkat first difference. 


\section{Uji Asumsi Klasik}

\section{a. Uji Normalitas}

Uji normalitas digunakan untuk mengetahui apakah resudial dari suatu model regresi terdistribusi normal. Uji normalitas dapat dilakukan dengan melihat nilai probabilitas Jarque-Berra.

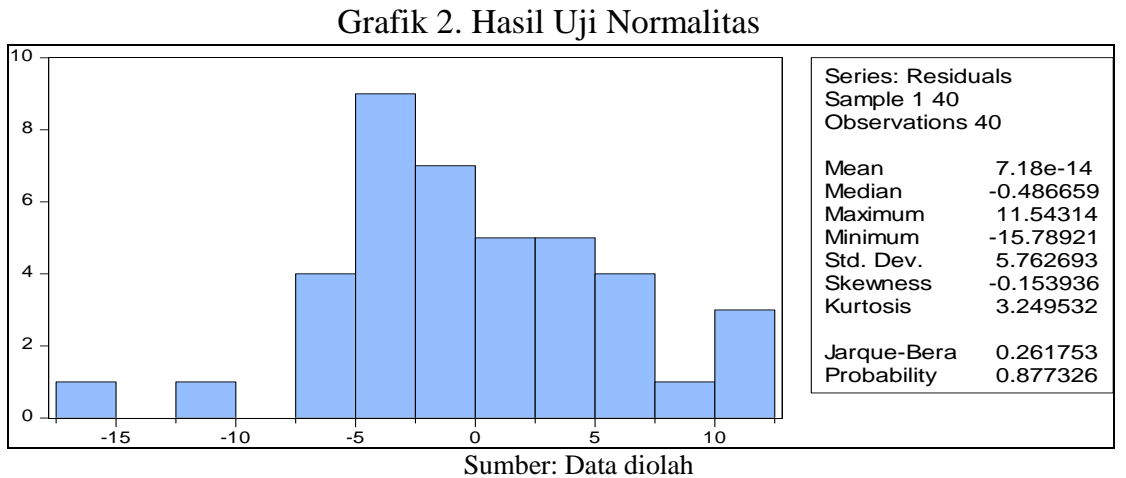

Berdasarkan hasil uji normalitas pada grafik 2 dapat dilihat nilai probabilitas Jarque-Bera yaitu 0.261753 atau lebih besar dari tingkat signifikansi 5\%. Hasil ini menunjukkan bahwa residual terdistribusi normal.

b. Uji Multikolinearitas

Tabel 5. Hasil Uji Multikolinearitas

\begin{tabular}{ccccc}
\hline & SIZE & ROA & ROE & DAR \\
\hline SIZE & 1.000000 & -0.101679 & 0.301838 & -0.181104 \\
\hline ROA & -0.101679 & 1.000000 & 0.671072 & -0.178606 \\
\hline ROE & 0.301838 & 0.671072 & 1.000000 & -0.016461 \\
\hline DAR & -0.181104 & -0.178606 & -0.016461 & 1.000000 \\
\hline \multicolumn{5}{c}{ Sumber: Data diolah }
\end{tabular}

Berdasarkan hasil uji multikolinearitas pada tabel 5 terlihat bahwa semua variabel independen dalam penelitian tidak ada yang melebihi nilai 0.80. Maka, dapat disimpulkan tidak ada korelasi yang kuat antar variabel independen dan telah lulus uji multikolinearitas.

c. Uji Heteroskedastisitas

Tabel 6. Uji Heteroskedastisitas

Heteroskedasticity Test: White

\begin{tabular}{llll}
\hline F-statistic & 0.322815 & Prob. F(4,35) & 0.8608 \\
\hline Obs*R-squared & 1.423217 & Prob. Chi-Square(4) & 0.8401 \\
\hline Scaled explained SS & 1.225602 & Prob. Chi-Square(4) & 0.8739 \\
\hline
\end{tabular}


Berdasarkan hasil uji White pada tabel 6 dapat dilihat nilai probabilitas $O b s^{*} R$-squared sebesar 0.8401 yang berarti lebih besar dari nilai signifikan $5 \%$ dan tidak ada gejala heteroskedastisitas dalam model penelitian.

d. Uji Autokorelasi

Tabel 7. Hasil Uji Autokorelasi

Breusch-Godfrey Serial Correlation LM Test:

\begin{tabular}{lcll}
\hline F-statistic & 2.328118 & Prob. F(2,33) & 0.1133 \\
\hline Obs*R-squared & 4.946045 & Prob. Chi-Square(2) & 0.0843 \\
\hline \multicolumn{4}{c}{ Sumber: Data diolah }
\end{tabular}

Berdasarkan hasil uji Breusch-Godfrey atau LM Test pada tabel 7 dapat dilihat bahwa nilai probabilitas $O b s^{*} R$-squared sebesar 0.0843 yang berarti lebih besar dari nilai signifikan 5\%. Maka, dapat disimpulkan bahwa dalam model penelitian tidak terdapat gejala autokorelasi.

3. Estimasi Model Data Panel

Model regresi linier berganda dalam penelitian ini menggunakan data panel, yaitu gabungan data silang (cross section) dan data runtut waktu (time series). Maka terlebih dahulu harus dilakukan uji model untuk menentukan metode pendekatan yang tepat antara pooled least square, fixed effect model, dan random effect model dengan melakukan uji chow dan uji hausman (Nachrowi dan Usman, 2006).

a. Uji Chow

Uji chow dilakukan untuk mengetahui model yang lebih tepat digunakan antara pooled least square atau fixed effect model.

Tabel 8. Hasil Uji Chow

\begin{tabular}{|c|c|c|c|}
\hline \multicolumn{4}{|c|}{ Redundant Fixed Effects Tests } \\
\hline \multicolumn{4}{|c|}{ Test cross-section fixed effects } \\
\hline Effects Test & Statistic & d.f. & Prob. \\
\hline Cross-section F & 4.615101 & $(7,28)$ & 0.0016 \\
\hline Cross-section Chi-square & 30.688888 & 7 & 0.0001 \\
\hline
\end{tabular}

Berdasarkan hasil uji Chow pada tabel 8 tersebut nilai probabilitas cross section $\mathrm{F}$ adalah $0.0016<0.05$, lebih tepat menggunakan fixed effect model dibandingkan dengan pooled least square.

b. Uji Hausman

Uji hausman dilakukan untuk mengetahui model yang lebih tepat digunakan antara fixed effect model atau random effect model.

Tabel 9. Hasil Uji Hausman

Correlated Random Effects - Hausman Test 


\begin{tabular}{|c|c|c|c|}
\hline \\
\hline \multicolumn{4}{|c|}{ Test cross-section random effects } \\
\hline Test Summary & Chi-Sq. Statistic & Chi-Sq. d.f. & Prob. \\
\hline Cross-section random & 1.343013 & 4 & 0.8540 \\
\hline
\end{tabular}

Berdasarkan hasil Uji Hausman pada tabel 9, nilai probabilitas cross section random adalah $0.8540>0.05$, maka lebih tepat menggunakan random effect model dibandingkan dengan fixed effect model.

4. Uji Statistik

a. Uji Adjusted $\mathrm{R}^{2}$ (Koefisien Determinasi)

Tabel 10. Hasil Uji Koefisien Determinasi

\begin{tabular}{lll}
\hline & Weighted Statistics & \\
\hline R-squared & 0.605389 Mean dependent var & 22.45409 \\
\hline Adjusted R-squared & 0.560290 S.D. dependent var & 6.718183 \\
\hline S.E. of regression & 4.454868 Sum squared resid & 694.6047 \\
\hline F-statistic & 13.4272 Durbin-Watson stat & 1.668964 \\
\hline Prob(F-statistic) & 0.000001 & \\
\hline
\end{tabular}

Koefisien determinasi bertujuan untuk mengukur kemampuan model dalam menerangkan variasi variabel dependen ISR oleh variabel independen Size, ROA, ROE, dan DAR. Semakin besar nilai Adjusted $\mathrm{R}^{2}$, maka semakin besar pula kemampuan variabel independen dalam menerangkan variabel dependen, begitu juga sebaliknya.

Pada tabel 10 dapat dilihat nilai Adjusted R-Squared sebesar 0.560290 atau sama dengan 56,03\% yang menunjukkan kemampuan variabel independen (Size, ROA, ROE, dan DAR,) dalam menjelaskan variabel dependen (ISR) adalah sebesar 56,03\% sedangkan sisanya sebesar $43,97 \%$ dijelaskan oleh variabel lain diluar penelitian.

b. Uji-F (Simultan)

Uji-F dilakukan untuk menguji apakah semua variabel independen dalam model regresi secara bersama-sama berpengaruh terhadap variabel dependen. Uji-F dapat dilihat pada tabel 10 nilai prob (F-Statistik) sebesar 0.000001 lebih kecil dari 0.05 yang berarti bahwa semua variabel independen dalam penelitian secara bersama-sama (simultan) berpengaruh terhadap variabel dependen.

c. Uji-t (Parsial)

Tabel 11. Hasil Uji-t

\begin{tabular}{crrrr}
\hline Variable & \multicolumn{1}{c}{ Coefficient } & \multicolumn{1}{c}{ Std. Error } & \multicolumn{1}{c}{ t-Statistic } & \multicolumn{1}{c}{ Prob. } \\
\hline C & -188.6115 & 44.21063 & -4.266203 & 0.0001 \\
\hline SIZE & 8.711333 & 1.457262 & 5.977879 & 0.0000 \\
\hline
\end{tabular}




\begin{tabular}{rrrrr}
\hline ROA & -2.149994 & 1.692098 & -1.270609 & 0.2122 \\
\hline ROE & 0.043093 & 0.099452 & 0.433303 & 0.6675 \\
\hline DAR & -0.068172 & 0.051379 & -1.326845 & 0.1932 \\
\hline
\end{tabular}

Sumber: Data diolah

Uji-t dilakukan untuk menunjukkan seberapa signifikan variabel independen secara individual terhadap variabel dependen. Hasilnya dapat dilihat dari nilai probabilitas variabel independen, jika dibawah tingkat signifikansi $5 \%$ atau 0,05 maka variabel tersebut memiliki pengaruh yang signifikan terhadap variabel dependen.

Berdasarkan tabel 11 dapat diketahui bahwa hanya ukuran perusahaan (size) yang berpengaruh signifikan terhadap pengungkapan Islamic social reporting (ISR), sedangkan variabel ROA, ROE, dan DAR tidak memiliki pengaruh signifikan terhadap pengungkapan Islamic social reporting (ISR).

\subsection{INTERPRETASI HASIL}

Berdasarkan pengujian hipotesis hasil penelitian yang telah dilakukan untuk mengetahui pengaruh size, profitabilitas yang diukur dengan ROA dan ROE, serta leverage yang diukur dengan DAR terhadap pengungkapan Islamic Social Reporting pada Bank Umum Syariah periode 2011-2015 yang disajikan pada pada tabel 12 (hasil Uji t), maka interpretasikan akan dijabarkan sebagai berikut

\section{Pengaruh Ukuran Perusahaan (Size) Terhadap ISR}

Ukuran perusahaan (size) memiliki nilai probabilitas sebesar 0.0000 lebih kecil dari taraf signifikansi 0.05. Maka dapat diartikan bahwa ukuran perusahaan berpengaruh signifikan terhadap Islamic Social Reporting. Sehingga, $\mathrm{H}_{\mathrm{a} 1}$ dalam penelitian ini diterima dan menolak $\mathrm{H}_{01}$. Hasil tersebut mendukung penelitian yang dilakukan oleh Othman, dkk. (2009,) Widyawati Raharja (2012), Taufik, dkk. (2015), Rosiana, dkk (2015).

Bank syariah yang memiliki total aset tinggi akan melakukan pengungkapan tanggung jawab sosial secara syariah lebih luas dibandingkan dengan bank syariah yang memiliki total aset lebih rendah. Hal ini dikarenakan sumber dana yang digunakan untuk melakukan aktivitas tanggung jawab sosial juga lebih banyak. Hasil ini sejalan teori dari Othman, dkk. (2009) bahwa perusahaan yang besar harus diikuti dengan penyaluran kegiatan sosial yang besar pula.

\section{Pengaruh Profitabilitas Terhadap ISR}

a. Pengaruh ROA Terhadap ISR

Profitabilitas yang diukur dengan ROA memiliki nilai probabilitas sebesar 0.2122 lebih besar dari taraf signifikansi 5\% atau 0.05, yang berarti ROA tidak memiliki pengaruh yang signifikan terhadap ISR. Maka, $\mathrm{H}_{02}$ dalam penelitian ini diterima dan menolak $\mathrm{H}_{\mathrm{a} 2}$. Hasil ini sejalan dengan teori intrumen oleh Burke \& Logsdon (1996) dalam Fitria dan Hartanti (2010) 
yang mengungkapkan bahwa kegiatan CSR merupakan strategi untuk mencapai tujuan perusahaan berupa reputasi yang positif dan strategi pemasaran jangka panjang.

Hasil penelitian ini mendukung penelitian sebelumnya yang telah dilakukan oleh Rosiana dkk. (2015). Haniffa (2002), menyatakan bahwa dalam pandangan Islam perusahaan yang memiliki niat untuk melakukan pengungkapan penuh tidak akan mempertimbangkan apakah perusahaan tersebut sedang dalam kondisi untung ataupun rugi.

\section{b. Pengaruh ROE Terhadap ISR}

Profitabilitas yang diukur dengan ROE memiliki nilai probabilitas sebesar 0.6675 lebih dari tingkat signifikansi $5 \%$ atau 0.05 , yang berarti tidak ada pengaruh yang signifikan antara ROE terhadap ISR. Maka, $\mathrm{H}_{03}$ dalam penelitian ini diterima dan menolak $\mathrm{H}_{\mathrm{a} 3}$. Hasil penelitian ini membuktikan bahwa bank syariah akan tetap melaksanakan kegiatan sosial perusahaan dan melakukan mengungkapkannya dalam laporan tahunan perusahaan meskipun profitabilitas perusahaan sedang naik atau turun.

Hasil ini juga mendukung teori stakeholder oleh Clarkson (1995) dalam Fitria dan Hartanti (2010) yang menyatakan bahwa manajemen perusahaan akan tetap melaporkan aktivitas perusahaan termasuk dalam bidang sosial meskipun profitabitas perusahaan sedang naik atau turun, karena perusahaan perlu mengakomodasi keinginan dan kebutuhan pemangku kepentingan (stakeholder) sehingga perusahaan dapat beraktivitas dengan baik dengan seluruh dukungan pemangku kepentingan tersebut.

\section{c. Pengaruh DAR Terhadap Pengungkapan ISR}

Leverage yang diukur dengan debt asset to ratio (DAR) tidak berpengaruh signifkan terhadap Islamic social reporting dengan nilai probabilitas sebesar 0.1932 lebih besar dari taraf signifikansi 5\% atau 0.05. dengan demikian $\mathrm{H}_{04}$ diterima menolak $\mathrm{H}_{\mathrm{a} 4}$. Tingkat utang yang tinggi pada bank syariah untuk menjalankan aktivitas operasionalnya, tidak menjadi pengaruh dalam melakukan kegiatan tanggung jawab sosial perusahaan.

Hasil ini mendukung penelitian yang dilakukan oleh Taufik dkk (2015), Rosiana dkk (2015). Hasil ini juga mendukung teori stakeholder oleh Clarkson (1995) dalam Fitria dan Hartanti (2010) bahwa perusahaan harus tetap menciptakan hubungan yang baik dengan para stakeholder dengan melakukan kegiatan CSR yang diungkapkan dalam laporan tahunan perusahaan walaupun saat tingkat leverage tinggi maupun rendah.

\section{d. Pengaruh Ukuran Perusahaan, Profitabilitas, dan Leverage Terhadap ISR}

Berdasarkan hasil penelitian dapat dilihat bahwa ukuran perusahaan (size), profitabilitas (ROA \& ROE), dan leverage (DAR) secara simultan mempengaruhi tingkat pengungkapan Islamic Social Reporting (ISR) dengan tingkat kemampuan sebesar 56,03\%, sedangkan sisanya sebesar 43,97\% dipengaruhi oleh variabel lain diluar penelitian. Maka $\mathrm{H}_{05}$ ditolak dan menerima $\mathrm{H}_{\mathrm{a} 5}$ yang berarti terdapat pengaruh yang signifikan antara ukuran 
perusahaan (size), ROA, ROE dan DAR terhadap Islamic Social Reporting (ISR) secara simultan. Hasil ini sejalan dengan teori stakeholder oleh Clarkson (1995) dalam Fitria dan Hartanti (2010) bahwa aktivitas CSR dilakukan untuk mengakomodasi keinginan dan kebutuhan pemangku kepentingan.

\section{SIMPULAN}

Perkembangan perbankan syariah di Indonesia mendorong kesadaran bank umum syariah dalam mengungkapkan pelaksanaan tanggung jawab sosial perusahaan yang merupakan salah satu fungsi bank syariah dalam melaksanakan kegiatan operasional perusahaan. Bedasarkan hasil pengujian yang telah dilakukan dapat disimpulkan beberapa hal, yaitu

1. Secara parsial Ukuran perusahaan yang diukur dengan total aset perusahaan berpengaruh signifikan terhadap pengungkapan ISR pada Bank Umum Syariah. Sedangkan, profitabilitas yang diukur dengan Return on Assets (ROA) dan Return on Equity (ROE) serta Leverage yang diukur dengan Debt to Asset Ratio (DAR) tidak berpengaruh signifikan terhadap terhadap pengungkapan ISR pada Bank Umum Syariah.

2. Secara silmultan terdapat pengaruh antara ukuran perusahaan, profitabilitas, dan leverage terhadap pengungkapan ISR pada Bank Umum Syariah di Indonesia.

Bank syariah diharapkan untuk terus dapat meningkatkan kinerja keuangannya, terutama dalam meningkatkan total aset yang dimiliki oleh bank syariah, karena sejalan dengan penelitian ini ditemukan bahwa ukuran perusahaan yang diukur dengan total aset perusahaan (size) akan mempengaruhi pelaporan ISR pada bank syariah di Indonesia. Kemudian, hadirnya indeks ISR dapat menjadi solusi bagi para regulator untuk menjadikan ISR sebagai pedoman bagi bank syariah dalam pelaksanaan laporan tanggung jawab sosial perusahaan dengan prespektif syariah, karena standar pelaporan CSR pada bank umum syariah saat ini yang masih mengacu pada standar bank konvensional yaitu dengan menggunakan indeks GRI.

\section{DAFTAR PUSTAKA}

Apriyanti, N. M. W., \& Budiasih, I. G. A. N. (2016). Profitabilitas Dan Corporate Social Responsibility Pada Perusahaan High Dan Low Profile. E-Jurnal Akuntansi, 977-1004.

Azhar, F. A., \& Trisnawati, R. (2013). Pengungkapan Islamic Social Reporting pada Bank Syariah di Indonesia. Fakultas Ekonomi dan 
Bisnis, Universitas Muhammadiyah Surakarta. Surakarta: Universitas Muhammadiyah Surakarta.

Dewi, A. S. M., \& Wirajaya, A. (2013). Pengaruh struktur modal, profitabilitas dan ukuran perusahaan pada nilai perusahaan. E-Jurnal Akuntansi, 358-372.

Fitria, S., \& Hartanti, D. (2010). Islam dan Tanggung Jawab Sosial: Studi Perbandingan Pengungkapan Bedasarkan Global Reporting Initiative Indeks dan Islamic Social Reporting Indeks. Simposium Nasional Akuntansi XIII Purwokerto 2010 (pp. 1-33). Purwokerto: Universitas Jendral Soedirman Purwokerto.

Ghazali, I., \& Ratmono, D. (2013). Analisis Multivariat dan Ekonometrika Teori, Konsep dan Aplikasi dengan Eviews 8. Semarang: Badan Penerbit Universitas Diponogoro.

Haniffa, R. M., \& Hudaib, M. A. (2002). A Theoritical Framework for the Development of the Islamic Prespective of Accounting. Accounting, Commerce, and Finance: The Islamic Prespective Journal, 1-42.

Haniffa, R. (2002). Social Reporting Disclosure: An Islamic Prespective. Indonesia Management \& Accounting Research, 128-146.

Haniffa, R., \& Hudaib, M. (2007). Exploring the Ethical Identity of Islamic. Journal of Business Ethics, 97-116.

Harahap, S. S. (2010). Analisis Kritis Laporan Keuangan. Jakarta: Rajawali Pers.

Ikatan Bankir Indonesia. (2014). Memahami Bisnis Bank Syariah. Jakarta: PT Gramedia Pustaka Utama.

Kamil, A., \& Herusetya, A. (2012). Pengaruh Karakteristik Perusahaan Terhadap Luas Pengungkapan Kegiatan Corporate Social Responsibility. Media Riset Akuntansi, 2(1).

Kasmir. (2010). Pengantar Manajemen Keuangan. Jakarta: Kencana.

Krippendorff, K. (2004). Content Analysis: An Introduction to Its Methodology. California: Saga Publication, Inc.

Muhammad, R. (2009). Studi Evaluatif Terhadap Laporan Perbankan Syariah. Jurnal Akuntansi dan Auditing Indonesia, 13(2), 189-208.

Nachrowi, N. D., \& Usman, H. (2006). Pendekatan Populer dan Praktis Ekonometrika untuk Analisis Ekonomi dan Keuangan: dilengkapi Teknik Analisis dan Pengolahan Data dengan SPSS dan EVIEWS. Jakarta: Lembaga Penerbit FE UI.

Othman, R., \& Thani, A. M. (2010). Islamic social reporting of listed companies in Malaysia. The International Business \& Economics Research Journal, 9(4), 135-144. 
Othman, R., Thani, A. M., \& Ghani, E. K. (2009). Determinants of Islamic social reporting among top Shariah-approved companies in Bursa Malaysia. Research Journal of International Studies, 12(10), 4-20.

Rosiana, R., Arifin, B., \& Hamdani, M. (2015). Pengaruh Ukuran Perusahaan, Profitabilitas, Leverage, dan Islamic Governance Score Terhadap Pengungkapan Islamic Social Reporting (Studi Empiris pada Bank Umum Syariah di Indonesia Tahun 2010-2012). Esensi: Jurnal Bisnis dan Manajemen, 5(1), 87-104.

Sofyani, H., Ulum, I., Syam, D., \& Wahjuni, S. (2012). Islamic social reporting index sebagai model pengukuran kinerja sosial perbankan syariah (studi komparasi Indonesia dan Malaysia). Jurnal Dinamika Akuntansi, 4(1), 36-46.

Sugiyono. (2008). Metode Penelitian Administrasi. Bandung: CV Alfabeta.

Taufik, dkk. (2015). Pengaruh Islamic Governance Score, Leverage dan Profitabilitas terhadap Islamic Social ReportingIndex pada Bank Umum Syariah di Indonesia. Jurnal Manajemen dan Bisnis Sriwijaya, 178-198.

Widyawati, S., \& Raharja, S. (2012). Analisis Faktor-Faktor yang Mempengaruhi Islamic Social Reporting: Perusahaan-Perusahaan yang Terdapat pada Daftar Efek Syariah Tahun 2009-2011. Diponegoro Journal of Accounting, 1-12.

Wiroso. (2009). Produk Perbankan Syariah. Jakarta: LPFE Usakti.

Undang-Undang Republik Indonesia Nomor 21 Tahun 2008 TentangPerbankanSyariah.

Peraturan Bank Indonesia Nomor 11/33/PBI/2009 Tentang Pelaksanaan Good Corporate Governance bagi Bank Umum Syariah dan Unit Usaha Syariah 